Riecfe / Redt in Der Banfpraris 



\section{bódftriđterliđe Entideibungen}

\section{รum

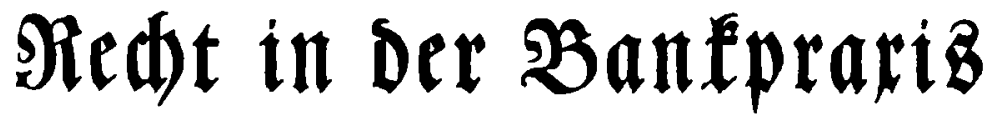

mit einem Bormort von

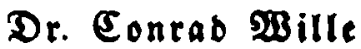

Qeiter ber Berufbffule fúr bas $B$ ant : unb

Berficerungsgewerbe in Berlin

beraugegeben von

Dr. Rarl:Seinz Riecte

Redtsanmalt in Berlin

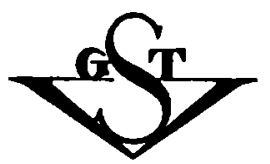

$\begin{array}{llll}1 & 9 & 3 & 7\end{array}$

Berlag oon Beorg Stilfe in Berlin 
Drud von g. beite S.m.b.6.. Grăfenbainthen 